\title{
Water Resources of East Carroll Parish, Louisiana
}

\section{Introduction}

Information concerning the availability, use, and quality of water in East Carroll Parish, Louisiana (fig. 1), is critical for proper water-supply management. The purpose of this fact sheet is to present information that can be used by water managers, parish residents, and others for stewardship of this vital resource. In 2014, 39.63 million gallons per day $(\mathrm{Mgal} / \mathrm{d})$ of water were withdrawn in East Carroll Parish: $32.43 \mathrm{Mgal} / \mathrm{d}$ from groundwater sources and 7.20 Mgal/d from surface-water sources ${ }^{1}$ (table 1). Withdrawals for agricultural use - composed of general irrigation, rice irrigation, and livestock - accounted for 97 percent $(38.55 \mathrm{Mgal} / \mathrm{d})$ of the total water withdrawn (table 2). Other categories of use included

${ }^{1}$ Water-withdrawal data are based on estimated or reported site-specific data and aggregated data, which are distributed to sources. For a full description of water-use estimate methodology, see "Data Collection" in Sargent (2011). Tabulation of numbers in text and tables may result in different totals because of rounding; nonrounded numbers are used for calculation of totals. public supply and rural domestic. Water-use data collected at 5-year intervals from 1960 to 2010 and again in 2014 indicated that water withdrawals peaked in 1980 at $47.96 \mathrm{Mgal} / \mathrm{d}$ (fig. 2).

\section{Groundwater Resources}

The primary freshwater-bearing aquifers in East Carroll Parish are the Mississippi River alluvial aquifer (also called the Mississippi River Valley alluvial aquifer in some publications) and Cockfield aquifer (figs. 1 and 3). In the central and western parts of the parish, the base of freshwater (water with a chloride concentration of 250 milligrams per liter $[\mathrm{mg} / \mathrm{L}]$ or less) ranges from an altitude of about 100 feet (ft) below the National Geodetic Vertical Datum of 1929 (NGVD 29) to greater than $400 \mathrm{ft}$ below NGVD 29 in the Cockfield aquifer. In the southern part of the parish, the base of fresh groundwater ranges from altitudes of about the NGVD 29 to greater than $100 \mathrm{ft}$ below NGVD 29 in the Mississippi River alluvial aquifer. Fresh groundwater is also

\section{EXPLANATION}

Approximate altitude of base of fresh groundwater, in feet below National Geodetic Vertical Datum of 1929 (NGVD 29) (modified from Smoot, 1988) - Deepest freshwater contained within the Cockfield aquifer, except where noted

0 to 49

50 to 99

100 to 199

200 to 299

300 to 399

400 to 499

500 to 599

600 to 699

700 to 899

900 to 999

1,000 and deeper

Approximate boundary of area showing deepest freshwater contained within the underlying Sparta and overlying alluvial aquifers

- $\cdots-$ River subbasin boundary

$A-A^{\prime}$ Line of section (see fig. 3; modified from Smoot, 1989)

Well for which hydrograph is shown (see fig. 4)

U.S. Geological Survey surface-water

streamflow site and number

$\nabla$ U.S. Geological Survey surface-water$07369700 \quad$ quality site and number (see table 4)

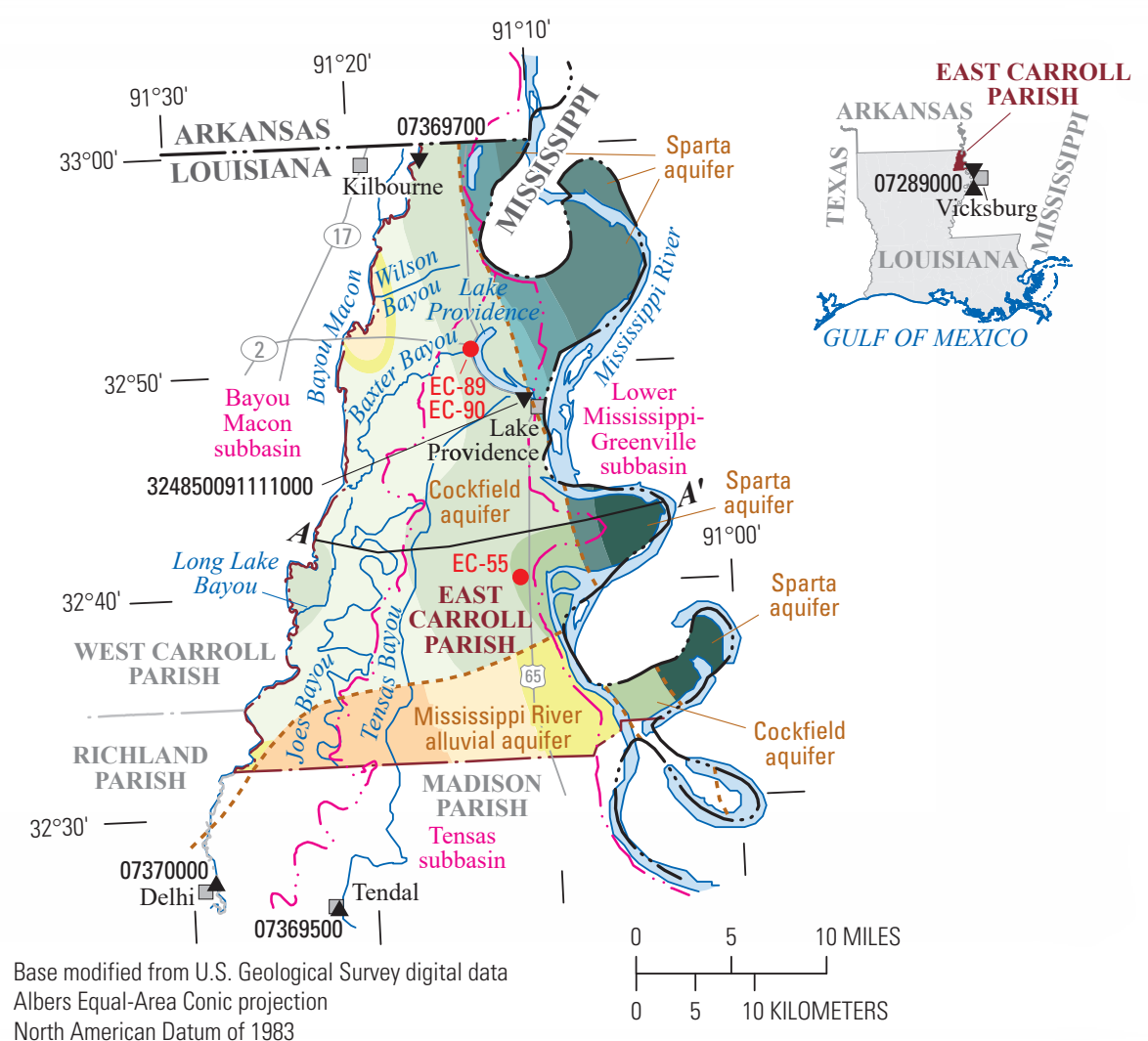

Figure 1. Location of study area, East Carroll Parish, Louisiana. 
Table 1. Water withdrawals, in million gallons per day, by source in East Carroll Parish, Louisiana, 2014 (Collier, 2018).

\begin{tabular}{lcc}
\hline $\begin{array}{c}\text { Aquifer or } \\
\text { surface-water body }\end{array}$ & Groundwater & $\begin{array}{c}\text { Surface } \\
\text { water }\end{array}$ \\
\hline $\begin{array}{c}\text { Mississippi River } \\
\text { alluvial aquifer }\end{array}$ & 31.36 & \\
Cockfield aquifer & 1.07 & \\
Bayou Macon & & 5.20 \\
Joes Bayou & & 1.12 \\
Tensas Bayou & & 0.40 \\
Miscellaneous & & 0.48 \\
$\quad$ surface waters & & \\
\cline { 2 - 3 } Total & $\mathbf{3 2 . 4 3}$ & $\mathbf{7 . 2 0}$ \\
\hline
\end{tabular}

Table 2. Water withdrawals, in million gallons per day, by use category in East Carroll Parish, Louisiana, 2014 (Collier, 2018).

$[<$, less than $]$

\begin{tabular}{lccr}
\hline \multicolumn{1}{c}{ Use category } & Groundwater & Surface water & \multicolumn{1}{c}{ Total } \\
\hline Public supply & 1.06 & 0.00 & 1.06 \\
Rural domestic & 0.01 & 0.00 & 0.01 \\
Livestock & $<0.01$ & $<0.01$ & $<0.01$ \\
Rice irrigation & 4.58 & 0.51 & 5.09 \\
General irrigation & 26.77 & 6.69 & 33.46 \\
\cline { 2 - 4 } Total & $\mathbf{3 2 . 4 3}$ & $\mathbf{7 . 2 0}$ & $\mathbf{3 9 . 6 3}$ \\
\hline
\end{tabular}

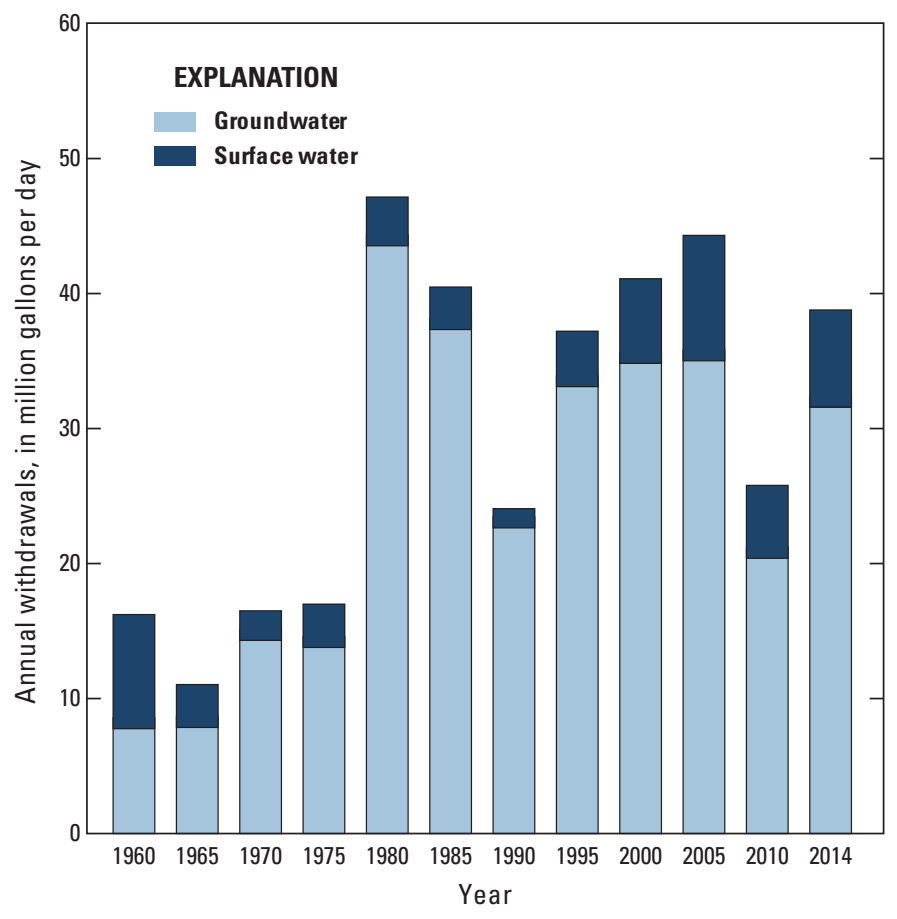

Figure 2. Water withdrawals in East Carroll Parish, Louisiana, 1960-2014 (Sargent, 2011; Collier, 2018). available at altitudes greater than 1,000 ft below NGVD 29 in the easternmost parts of the parish in the Sparta aquifer; because no withdrawals were reported in 2014, this aquifer is not discussed further (fig. 1; Smoot, 1988).

\section{Mississippi River Alluvial Aquifer}

The Mississippi River alluvial aquifer, which extends across East Carroll Parish, is a large regional aquifer present in various States. The alluvial sediments deposited by the Mississippi River generally grade from silt and clay at the surface to coarse sand and gravel at the base and range in thickness from less than $100 \mathrm{ft}$ in the northwestern part of the parish to greater than $180 \mathrm{ft}$ in the southeastern part. The Mississippi River alluvial aquifer is composed of the sand and gravel portion of the alluvial sediments. The altitude of the base of the aquifer ranges from greater than NGVD 29 in the northwestern and western parts of the parish to greater than $60 \mathrm{ft}$ below NGVD 29 in the southern part (Whitfield, 1975).

In 1990, a regional survey of water-level altitudes indicated that levels in wells screened in the Mississippi River alluvial aquifer ranged from greater than $80 \mathrm{ft}$ above NGVD 29 in the northern part of the parish to less than $60 \mathrm{ft}$ above NGVD 29 in the extreme southern part of the parish (Seanor and Smoot, 1995). Water levels at well EC-55, screened in the Mississippi River alluvial aquifer and located about 1 mile (mi) from the Mississippi River in East Carroll Parish (fig. 1), fluctuated up to $10 \mathrm{ft}$ or more annually in response to changes in river stage and indicated little long-term trend from the mid-1950s to 2016 (fig. 4). Water levels at well EC-90, which is also screened in the Mississippi River alluvial aquifer in East Carroll Parish, but located about $4.6 \mathrm{mi}$ west of the Mississippi River (fig. 1), generally fluctuated less than $10 \mathrm{ft}$ annually and declined less than about $5 \mathrm{ft}$ from the mid-1950s to 2009 (fig. 4). The primary source of recharge to this aquifer is precipitation. Groundwater in the aquifer moves in a general southerly direction but may move into or out of streams depending on water levels in the aquifer and those streams (Whitfield, 1975; Seanor and Smoot, 1995).

State well-registration records listed 792 active water wells screened in the Mississippi River alluvial aquifer in East Carroll Parish in 2016: 761 irrigation wells, 27 domestic wells, 2 publicsupply wells, and 2 industrial wells. Well depths ranged from 32 to $151 \mathrm{ft}$ below land surface, and reported yields ranged from 5 to 4,600 gallons per minute (gal/min) (Louisiana Department of Natural Resources, 2016). In 2014, about 31.36 Mgal/d were withdrawn from the Mississippi River alluvial aquifer (table 1): $0.01 \mathrm{Mgal} / \mathrm{d}$ for rural domestic, $26.77 \mathrm{Mgal} / \mathrm{d}$ for general irrigation, less than $0.01 \mathrm{Mgal} / \mathrm{d}$ for livestock, and $4.58 \mathrm{Mgal} / \mathrm{d}$ for rice irrigation (Collier, 2018).

\section{Cockfield Aquifer}

The Cockfield aquifer is a regional aquifer that contains freshwater in much of northeastern and parts of west-central Louisiana (Brantly and Seanor, 1996). The Cockfield aquifer underlies the Mississippi River alluvial aquifer in East Carroll Parish, and these aquifers are in direct hydraulic connection (fig. 3). The hydraulic connection between the two aquifers allows the Mississippi River alluvial aquifer to recharge the Cockfield aquifer. Historically, water levels in the Cockfield closely mimic those of the Mississippi River alluvial aquifer where the aquifers are connected (Brantly and Seanor, 1996). The Cockfield aquifer dips to the southeast, and freshwater is available from the Cockfield aquifer in all but the southernmost part of East Carroll Parish (Smoot, 1988) (fig. 1). 


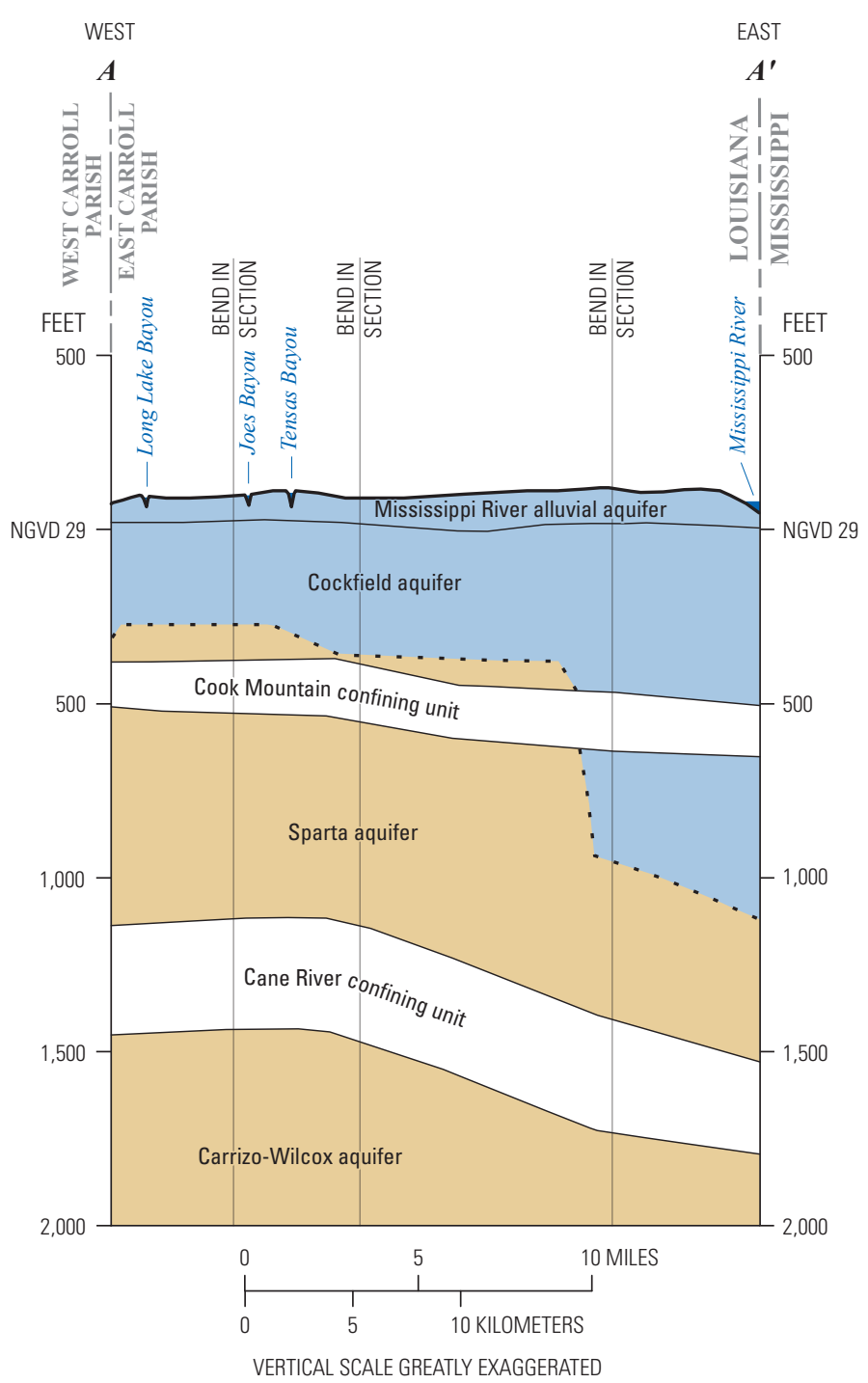

EXPLANATION

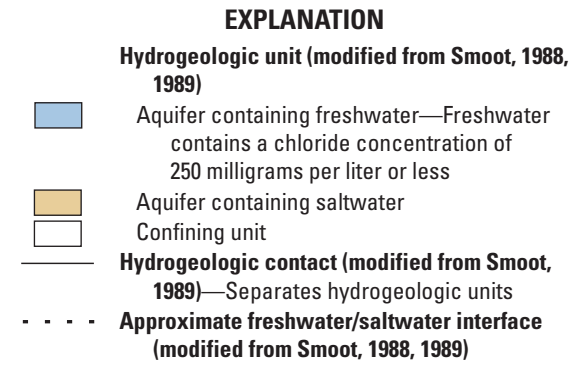

NGVD 29, National Geodetic Vertical Datum of 1929

Figure 3. Idealized west-to-east hydrogeologic section through East Carroll Parish, Louisiana, showing aquifer and confining unit intervals (individual sand and clay layers not shown). Trace of section shown on figure 1.

In 1993, a study of water-level altitudes in wells screened in the Cockfield aquifer indicated that levels ranged from 64 to $85 \mathrm{ft}$ above NGVD 29 in the parish, with flow in a general southerly direction (Brantly and Seanor, 1996). Water levels at well EC-89, located near well EC-90 (fig. 1), closely mimic water levels in the Mississippi River alluvial aquifer at well EC-90 because of the direct hydraulic connection between the aquifers. The water level at well EC-89 generally fluctuated less than $10 \mathrm{ft}$ annually and declined less than about $5 \mathrm{ft}$ from the mid-1950s to the mid-2010s (fig. 4).
State well-registration records listed 25 active water wells screened in the Cockfield aquifer in East Carroll Parish in 2016: 10 domestic wells, 12 public-supply wells, 1 industrial well, and 2 irrigation wells. Well depths ranged from 110 to $500 \mathrm{ft}$ below land surface, and reported yields ranged from 10 to $1,096 \mathrm{gal} / \mathrm{min}$ (Louisiana Department of Natural Resources, 2016). In 2014, $1.07 \mathrm{Mgal} / \mathrm{d}$ were withdrawn from the Cockfield aquifer (table 1) with use categories including less than $0.01 \mathrm{Mgal} / \mathrm{d}$ for livestock, $1.06 \mathrm{Mgal} / \mathrm{d}$ for public supply, and less than 0.01 for rural domestic use (Collier, 2018).

\section{Groundwater Quality}

In East Carroll Parish, groundwater samples were collected from 25 wells screened in the Mississippi River alluvial aquifer during 1943-2011 and from 39 wells screened in the Cockfield aquifer during 1926-86 as part of an ongoing program to monitor the State's groundwater resources. These samples had median values that are within the U.S. Environmental Protection Agency's Secondary Maximum Contaminant Levels ${ }^{2}$ (SMCLs) for color and $\mathrm{pH}$ and concentrations of chloride and sulfate (table 3 ). The median dissolved-solids concentration was within the SMCL for the Mississippi River alluvial aquifer and exceeded the SMCL in the Cockfield aquifer. The median hardness value of $330 \mathrm{mg} / \mathrm{L}$ for the Mississippi River alluvial aquifer was within the very hard range, ${ }^{3}$ and the median hardness value of $85.5 \mathrm{mg} / \mathrm{L}$ for the Cockfield aquifer was within the moderately hard range.

\section{Surface-Water Resources}

Surface-water resources in East Carroll Parish are present primarily in three drainage subbasins (fig. 1). The Bayou Macon subbasin (Hydrologic Unit Code [HUC] 08050002) drains the western part of the parish, the Tensas subbasin (HUC 08050003) drains the central part of the parish, and the Lower MississippiGreenville subbasin (HUC 08030100) drains the area adjacent to the eastern border of the parish (U.S. Geological Survey [USGS], 2016). The natural hydrology of these subbasins has been modified by numerous stream channel modifications, including levees and ditches (USGS, 2016). In 2014, $0.48 \mathrm{Mgal} / \mathrm{d}$ were withdrawn from miscellaneous streams within the parish (table 1): less than $0.01 \mathrm{Mgal} / \mathrm{d}$ for livestock, $0.08 \mathrm{Mgal} / \mathrm{d}$ for rice irrigation, and $0.40 \mathrm{Mgal} / \mathrm{d}$ for general irrigation (Collier, 2018).

\section{Bayou Macon Subbasin}

Bayou Macon is the primary drainage of the Bayou Macon subbasin. The bayou originates in southeastern Arkansas and flows in a general southerly direction into Louisiana along much of the western border of East Carroll Parish. Bayou Macon receives flow from Long Lake Bayou, Baxter Bayou, and Wilson Bayou. The average streamflow for Bayou Macon near Delhi (USGS site number 07370000), located south of East Carroll Parish on the border of Richland and Madison Parishes (fig. 1), was 975 cubic feet per second $\left(\mathrm{ft}^{3} / \mathrm{s}\right)$ during the period 1934-92 (USGS, 2016). In 2014, 5.20 Mgal/d were withdrawn from Bayou

${ }^{2}$ The SMCLs are Federal guidelines regarding cosmetic effects (such as tooth or skin discoloration), aesthetic effects (such as taste, odor, or color), or technical effects (such as damage to water equipment or reduced effectiveness of treatment for other contaminants) of potential constituents of drinking water. SMCLs were established as guidelines by the U.S. Environmental Protection Agency (2016).

${ }^{3}$ Hardness ranges, expressed as milligrams per liter of calcium carbonate, are as follows: 0-60, soft; 61-120, moderately hard; 121-180, hard; greater than 180, very hard (Hem, 1985). 


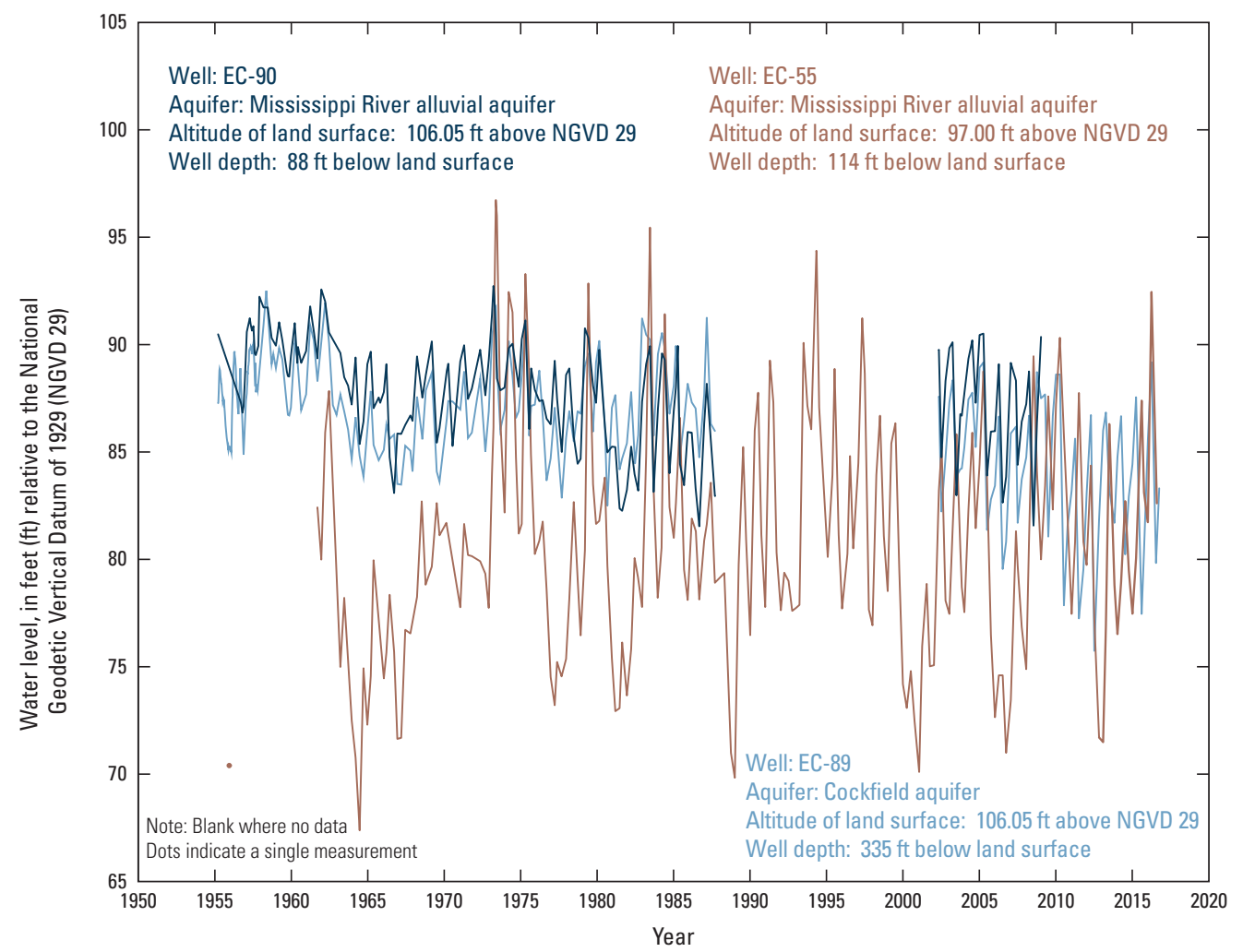

Figure 4. Water levels in well EC-55 and well EC-90 screened in the Mississippi River alluvial aquifer and well EC-89 screened in the Cockfield aquifer in East Carroll Parish, Louisiana (see fig. 1 for well location; U.S. Geological Survey, 2016a).

Table 3. Summary of selected water-quality characteristics for 25 freshwater wells screened in the Mississippi River alluvial aquifer and 39 wells screened in the Cockfield aquifer in East Carroll Parish, Louisiana (U.S. Geological Survey, 2016).

[Values are in milligrams per liter, except as noted. $\mu \mathrm{S} / \mathrm{cm}$, microsiemens per centimeter; ${ }^{\circ} \mathrm{C}$, degrees Celsius; $\mathrm{SU}$, standard unit; $\mathrm{CaCO}_{3}$, calcium carbonate; $\mu \mathrm{g} / \mathrm{L}$, micrograms per liter; SMCL, Secondary Maximum Contaminant Level established by the U.S. Environmental Protection Agency (2016); NA, not applicable]

\begin{tabular}{|c|c|c|c|c|c|c|c|c|c|c|c|c|c|}
\hline & $\begin{array}{l}\text { Tem- } \\
\text { perature } \\
\left({ }^{\circ} \mathrm{C}\right)\end{array}$ & $\begin{array}{c}\text { Color } \\
\text { (plati- } \\
\text { num } \\
\text { cobalt } \\
\text { units) }\end{array}$ & $\begin{array}{c}\text { Specific } \\
\text { conduc- } \\
\text { tance, field } \\
(\mu \mathrm{S} / \mathrm{cm} \text { at } \\
\left.25^{\circ} \mathrm{C}\right)\end{array}$ & $\begin{array}{l}\mathrm{pH}, \\
\text { field } \\
\text { (SU) }\end{array}$ & $\begin{array}{l}\text { Hard- } \\
\text { ness } \\
\text { (as } \\
\mathrm{CaCO}_{3} \text { ) }\end{array}$ & $\begin{array}{c}\text { Cal- } \\
\text { cium, } \\
\text { filtered } \\
\text { (as Ca) }\end{array}$ & $\begin{array}{l}\text { Mag- } \\
\text { nesium, } \\
\text { filtered } \\
\text { (as Mg) }\end{array}$ & $\begin{array}{l}\text { Sodium, } \\
\text { filtered } \\
\text { (as Na) }\end{array}$ & $\begin{array}{l}\text { Chlo- } \\
\text { ride, } \\
\text { filtered } \\
\text { (as Cl) }\end{array}$ & $\begin{array}{c}\text { Sulfate, } \\
\text { filtered } \\
\text { (as } \\
\mathrm{SO}_{4} \text { ) }\end{array}$ & $\begin{array}{l}\text { Iron, } \\
\text { filtered, } \\
\text { in } \mu \mathrm{g} / \mathrm{L} \\
\text { (as Fe) }\end{array}$ & $\begin{array}{c}\text { Man- } \\
\text { ganese, } \\
\text { filtered, } \\
\text { in } \mu \mathrm{g} / \mathrm{L} \\
\text { (as Mn) }\end{array}$ & $\begin{array}{l}\text { Dis- } \\
\text { solved } \\
\text { solids, } \\
\text { filtered }\end{array}$ \\
\hline \multicolumn{14}{|c|}{ Mississippi River alluvial aquifer (1943-2011) } \\
\hline Median & 19.9 & 5 & 733 & 7.2 & 330 & 91.5 & 29 & 24 & 8.3 & 18 & 5,000 & 676 & 455 \\
\hline 10th percentile & 19.2 & 0 & 557 & 6.9 & 264.8 & 68.9 & 21.5 & 11 & 3.9 & 1.2 & 156 & 122 & 318 \\
\hline 90th percentile & 20 & 10 & 1,220 & 8.1 & 407.6 & 110 & 34 & 47 & 32.2 & 41 & 8,200 & 993 & 764 \\
\hline $\begin{array}{c}\text { Number of } \\
\text { samples }\end{array}$ & 15 & 11 & 16 & 10 & 17 & 16 & 16 & 11 & 25 & 11 & 13 & 12 & 11 \\
\hline $\begin{array}{l}\text { Percentage of } \\
\text { samples that } \\
\text { do not exceed } \\
\text { SMCLs }\end{array}$ & NA & 91 & NA & 100 & NA & NA & NA & NA & 100 & 100 & 23 & 8 & 55 \\
\hline \multicolumn{14}{|c|}{ Cockfield aquifer (1926-86) } \\
\hline Median & 21 & 5 & 878 & 7.6 & 85.5 & 22 & 8.4 & 140 & 50.5 & 0.6 & 565 & 170 & 525 \\
\hline 10th percentile & 20 & 0 & 568 & 7.1 & 10.7 & 3.6 & 1.0 & 26 & 8.9 & 0 & 85 & 20 & 334 \\
\hline 90th percentile & 21.5 & 380 & 1,289 & 8.3 & 340 & 95 & 27.8 & 270 & 110 & 4 & 2,080 & 365 & 859 \\
\hline $\begin{array}{c}\text { Number of } \\
\text { samples }\end{array}$ & 19 & 36 & 32 & 35 & 40 & 34 & 34 & 31 & 40 & 35 & 22 & 10 & 35 \\
\hline $\begin{array}{l}\text { Percentage of } \\
\text { samples that } \\
\text { do not exceed } \\
\text { SMCLs }\end{array}$ & NA & 75 & NA & 94 & NA & NA & NA & NA & 98 & 100 & 41 & 30 & 40 \\
\hline SMCLs & NA & 15 & NA & $6.5-8.5$ & NA & NA & NA & NA & 250 & 250 & 300 & 50 & 500 \\
\hline
\end{tabular}


Table 4. Summary of selected water-quality characteristics for samples from the Mississippi River at Vicksburg, Mississippi; Lake Providence near Lake Providence, Louisiana; and Bayou Macon near Kilbourne, Louisiana (U.S. Geological Survey, 2016).

[Values are in milligrams per liter, except as noted. $\mu \mathrm{S} / \mathrm{cm}$, microsiemens per centimeter; ${ }^{\circ} \mathrm{C}$, degrees Celsius; $\mathrm{SU}$, standard unit; $\mathrm{CaCO}$, calcium carbonate; $\mu \mathrm{g} / \mathrm{L}$, micrograms per liter; <, less than; SMCL, Secondary Maximum Contaminant Level established by the U.S. Environmental Protection Agency (2016); NA, not applicable]

\begin{tabular}{|c|c|c|c|c|c|c|c|c|c|}
\hline & $\begin{array}{l}\text { Color } \\
\text { (platinum } \\
\text { cobalt } \\
\text { units) }\end{array}$ & $\begin{array}{c}\text { Specific } \\
\text { conduc- } \\
\text { tance, field } \\
(\mu \mathrm{S} / \mathrm{cm} \text { at } \\
25^{\circ} \mathrm{C} \text { ) }\end{array}$ & $\begin{array}{c}\text { Dissolved } \\
\text { oxygen }\end{array}$ & $\begin{array}{l}\text { pH, field } \\
\text { (SU) }\end{array}$ & $\begin{array}{l}\text { Hardness } \\
\text { (as } \mathrm{CaCO}_{3} \text { ) }\end{array}$ & $\begin{array}{l}\text { Chloride, } \\
\text { filtered } \\
\text { (as CI) }\end{array}$ & $\begin{array}{l}\text { Iron, } \\
\text { filtered, in } \\
\mu \mathrm{g} / \mathrm{L} \text { (as Fe) }\end{array}$ & $\begin{array}{c}\text { Manganese, } \\
\text { filtered, } \\
\text { in } \mu g / L \\
\text { (as Mn) }\end{array}$ & $\begin{array}{l}\text { Dissolved } \\
\text { solids, } \\
\text { filtered }\end{array}$ \\
\hline \multicolumn{10}{|c|}{ Mississippi River at Vicksburg, Miss. (1961-99) ${ }^{1}$} \\
\hline Median & 15 & 370 & 8.2 & 7.7 & 147 & 18 & 20 & $<10$ & 228 \\
\hline 10th percentile & 7 & 280 & 6.5 & 7.3 & 120 & 13 & $<6.3$ & $<2$ & 170 \\
\hline 90th percentile & 20 & 440 & 11.5 & 8 & 170 & 26 & 90 & 20 & 271 \\
\hline Number of samples & 5 & 160 & 146 & 158 & 155 & 156 & 89 & 72 & 154 \\
\hline $\begin{array}{l}\text { Percentage of samples } \\
\text { that do not exceed } \\
\text { SMCLs }\end{array}$ & 60 & NA & NA & 97 & NA & 100 & 98 & 93 & 100 \\
\hline \multicolumn{10}{|c|}{ Lake Providence near Lake Providence, La. $(1976-85)^{2}$} \\
\hline Median & 5 & 183 & 9.7 & 8 & 76 & 4.0 & 20 & $<10$ & 103 \\
\hline 10th percentile & 2 & 140 & 4.5 & 7.3 & 58 & 3.0 & $<10$ & $<10$ & 82 \\
\hline 90th percentile & 20 & 219 & 12.5 & 8.7 & 87.6 & 5.1 & 46 & 10 & 115 \\
\hline Number of samples & 35 & 54 & 54 & 47 & 37 & 36 & 8 & 5 & 36 \\
\hline $\begin{array}{l}\text { Percentage of samples } \\
\text { that do not exceed } \\
\text { SMCLs }\end{array}$ & 83 & NA & NA & 68 & NA & 100 & 100 & 100 & 100 \\
\hline \multicolumn{10}{|c|}{ Bayou Macon near Kilbourne, La. (1957-91)³ } \\
\hline Median & 15 & 290 & 7.8 & 7.3 & 120 & 13.5 & 50 & 50 & 186 \\
\hline 10th percentile & 5 & 124 & 6.1 & 6.7 & 52 & 4.9 & $<10$ & 18 & 110 \\
\hline 90th percentile & 60 & 421 & 10.9 & 7.9 & 170 & 25.9 & 220 & 144 & 247 \\
\hline Number of samples & 86 & 112 & 58 & 113 & 101 & 114 & 8 & 9 & 82 \\
\hline $\begin{array}{l}\text { Percentage of samples } \\
\text { that do not exceed } \\
\text { SMCLs }\end{array}$ & 57 & NA & NA & 95 & NA & 100 & 88 & 56 & 100 \\
\hline SMCL & 15 & NA & NA & $6.5-8.5$ & NA & 250 & 300 & 50 & 500 \\
\hline \multicolumn{10}{|c|}{${ }^{1}$ U.S. Geological Survey site number 07289000 (see fig. 1). } \\
\hline \multicolumn{10}{|c|}{${ }^{2}$ U.S. Geological Survey site number 324850091111000 (see fig. 1). } \\
\hline${ }^{3}$ U.S. Geological Survey s & & 700 (see fig. 1) & & & & & & & \\
\hline
\end{tabular}

Macon: $0.38 \mathrm{Mgal} / \mathrm{d}$ for rice irrigation and 4.82 Mgal/d for general irrigation. Also in 2014, $1.12 \mathrm{Mgal} / \mathrm{d}$ were withdrawn from Joes Bayou: $0.05 \mathrm{Mgal} / \mathrm{d}$ for rice irrigation and $1.07 \mathrm{Mgal} / \mathrm{d}$ for general irrigation (Collier, 2018).

\section{Tensas Subbasin}

Tensas Bayou is the primary drainage of the Tensas subbasin and originates in East Carroll Parish as an outflow of Lake Providence, meanders through the central part of the parish, and flows into Madison Parish (fig. 1). Tensas Bayou eventually becomes the Tensas River south of East Carroll Parish. The annual average streamflow of the Tensas River at Tendal (USGS site number 07369500), located south of East Carroll Parish (fig. 1), was about $358 \mathrm{ft}^{3} / \mathrm{s}$ during 1935-2015 (USGS, 2016). During this period, the highest monthly average streamflow occurred during February $\left(666 \mathrm{ft}^{3} / \mathrm{s}\right)$ and the lowest during August $\left(83.9 \mathrm{ft}^{3} / \mathrm{s}\right)$. In 2014, an estimated $0.40 \mathrm{Mgal} / \mathrm{d}$ were withdrawn from Tensas Bayou for general irrigation (Collier, 2018).
Lake Providence is located near the town of Lake Providence in the central part of the parish near the Mississippi River. This oxbow lake is a former Mississippi River channel that was cut off from the current river path hundreds of years ago. The lake is approximately 1,380 acres in surface area, with a maximum depth of $37 \mathrm{ft}$ and an average depth of $12 \mathrm{ft}$. Lake levels are maintained through artificial control structures and fluctuate naturally from about 1 to $4 \mathrm{ft}$. Lake Providence is used for recreational fishing and skiing and for local irrigation (Louisiana Department of Wildlife and Fisheries, 2015).

\section{Lower Mississippi-Greenville Subbasin}

The Lower Mississippi-Greenville subbasin drains relatively little land in the parish because of the presence of levees along the Mississippi River. However, the upstream drainage area includes more than 40 percent of the conterminous United States and contributed to an annual average flow of the Mississippi River at Vicksburg, Mississippi (site number 07289000; fig. 1), 
of about $689,700 \mathrm{ft}^{3} / \mathrm{s}$ for the period 2007-14 from a drainage area of 1,144,500 square miles (USGS, 2016). During this period, the highest and lowest monthly average streamflows at the site were during May (1,199,000 ft $3 / \mathrm{s})$ and September $\left(393,500 \mathrm{ft}^{3} / \mathrm{s}\right)$, respectively. In 2011, a high of 2,310,000 $\mathrm{ft}^{3} / \mathrm{s}$ was recorded, and in 2012, a low of $191,000 \mathrm{ft}^{3} / \mathrm{s}$ was recorded.

\section{Surface-Water Quality}

Surface-water samples were collected from the Mississippi River at Vicksburg, Mississippi, during 1961-99, Lake Providence (USGS site number 324850091111000) during 1976-85, and Bayou Macon near Kilbourne (USGS site number 07369700) during 1957-91 (fig. 1) as part of an ongoing program to monitor the State's surface-water resources. These samples were within SMCLs for concentrations of chloride and dissolved solids (table 4). Median values for dissolved-oxygen concentrations for all three sites were greater than $7.5 \mathrm{mg} / \mathrm{L} ; 5 \mathrm{mg} / \mathrm{L}$ is considered the minimum value for a diverse population of fresh, warmwater biota, including sport fish (Louisiana Department of Environmental Quality, 2008).

Natural processes and agricultural, municipal, and industrial activities in the Mississippi River basin upstream of East Carroll Parish affect water quality in Mississippi River water available to the parish. Water-quality constituents, such as concentrations of agricultural pesticides and nutrients, are generally highest in spring-early summer, commonly referred to as the "spring flush," which results from the runoff of upstream applications (Demcheck and others, 2004). Suspended-sediment concentrations are generally highest in late winter and early spring and generally lowest in late summer and fall (Wells, 1980).

\section{References Cited}

Brantly, J.A., and Seanor, R.C., 1996, Louisiana ground-water map no. 9 Potentiometric surface, 1993, and water-level changes, 1968-93, of the Cockfield aquifer in northern Louisiana: U.S. Geological Survey WaterResources Investigations Report 95-4241, 2 sheets. [Also available at http://pubs.er.usgs.gov/publication/wri954241.]

Collier, A.L., 2018, Water withdrawals by source and category in Louisiana Parishes, 2014-2015: U.S. Geological Survey data release, https://doi. org/10.5066/F78051VM.

Demcheck, D.K., Tollett, R.W., Mize, S.V., Skrobialowski, S.C., Fendick, R.B., Jr., Swarzenski, C.M., and Porter, Stephen, 2004, Water quality in the Acadian-Pontchartrain drainages, Louisiana and Mississippi, 1999-2001: U.S. Geological Survey Circular 1232, 41 p. [Also available at http://pubs.water.usgs.gov/cir1232.]

Hem, J.D., 1985, Study and interpretation of the chemical characteristics of natural water ( $3 \mathrm{~d}$ ed.): U.S. Geological Survey Water-Supply Paper 2254, 264 p., accessed February 20, 2013, at http://pubs.er.usgs.gov/ publication/wsp2254.

Louisiana Department of Environmental Quality, 2008, Environmental Regulatory Code, Title 33, Part IX, Subpart 1: Baton Rouge, Louisiana Department of Environmental Quality, accessed June 9, 2009, at http://www.deq.louisiana.gov/portal/tabid/1674/Default.aspx.

Louisiana Department of Natural Resources, 2016, Strategic Online Natural Resources Information System (SONRIS): Louisiana Department of Natural Resources database, accessed August 25, 2016, at http://sonris. $\mathrm{com} /$.

Louisiana Department of Wildlife and Fisheries, 2015, Waterbody Management Plans - Inland: Baton Rouge, Louisiana Department of Wildlife and Fisheries, accessed January 9, 2017, at http://www.wlf. louisiana.gov/fishing/waterbody-management-plans-inland.
Sargent, B.P., 2011, Water use in Louisiana, 2010: Louisiana Department of Transportation and Development Water Resources Special Report no. $17,135 \mathrm{p}$.

Seanor, R.C., and Smoot, C.W., 1995, Louisiana ground-water map no. 6 Potentiometric surface, 1990, and water-level changes, 1974-90, of the Mississippi River alluvial aquifer in northeastern Louisiana: U.S. Geological Survey Water-Resources Investigations Report 95-4146, 2 sheets.

Smoot, C.W., 1988, Louisiana hydrologic atlas map no. 3-Altitude of the base of freshwater in Louisiana: U.S. Geological Survey Water-Resources Investigations Report 86-4314, 1 sheet, accessed November 2, 2011, at https://pubs.er.usgs.gov/publication/wri864314.

Smoot, C.W., 1989, Louisiana hydrologic atlas map no. 4-Geohydrologic sections of Louisiana: U.S. Geological Survey Water-Resources Investigations Report 87-4288, 1 sheet. [Also available at https://pubs. usgs.gov/wri/1987/4288/plate-1.pdf.]

U.S. Environmental Protection Agency, 2016, Secondary Drinking Water Standards - Guidance for nuisance chemicals, accessed April 13, 2016, at https:/www.epa.gov/dwstandardsregulations/secondary-drinkingwater-standards-guidance-nuisance-chemicals.

U.S. Geological Survey [USGS], 2016, National Water Information System-Web interface, accessed November 30, 2016, at http://dx.doi. org/10.5066/F7P55KJN.

Wells, F.C., 1980, Hydrology and water quality of the lower Mississippi River: Louisiana Department of Transportation and Development, Office of Public Works Water Resources Technical Report no. 21, 83 p. [Also available at http://la.water.usgs.gov/publications/pdfs/TR21.pdf.]

Whitfield, M.S., Jr., 1975, Geohydrology and water quality of the Mississippi River alluvial aquifer, northeastern Louisiana: Louisiana Department of Public Works Water Resources Technical Report no. 10, 29 p. [Also available at https://la.water.usgs.gov/publications/pdfs/ TR10.pdf.]

This fact sheet has been prepared by the USGS, in cooperation with the Louisiana Department of Transportation and Development (DOTD), as part of a program to document water use, availability, and quality in the parishes of Louisiana. Information on the availability, past and current water use, use trends, and water quality from groundwater and surface-water sources in the parish is presented here. Previously published reports (see References Cited section) and data stored in the USGS National Water Information System (USGS, 2016) are the primary sources of the information presented here. Special thanks are given to Doug Taylor, Director, and Zahir "Bo" Bolourchi (retired), DOTD Cooperative Program with the USGS.

\section{By Vincent E. White}

\section{For additional information, contact:}

Director, USGS Lower Mississippi-Gulf Water Science Center 3535 S. Sherwood Forest Blvd., Suite 120

Baton Rouge, LA 70816

E-mail: gs-w-lmg_center_director@usgs.gov

Fax: (225) 298-5490

Telephone: (225) 298-5481

Home Page: http://la.water.usgs.gov 